\title{
PENGARUH PEMERIKSAAN PAJAK TERHADAP KEPATUHAN WAJIB PA- JAK DAN DAMPAKNYA TERHADAP EFEKTIVITAS PENERIMAAN PAJAK PENGHASILAN BADAN
}

\author{
Neng Siti Rohmatul Wahda \\ Sekolah Tinggi Ilmu Ekonomi Muhammadiyah Bandung, Indonesia \\ nenk.wahda@gmail.com
}

\section{Agus Bagianto}

Dosen Sekolah Tinggi Ilmu Ekonomi Muhammadiyah Bandung, Indonesia agusbagianto@stiemb.ac.id

\section{Yuniati}

Dosen Sekolah Tinggi Ilmu Ekonomi Muhammadiyah Bandung, Indonesia yuniati@stiemb.ac.id

\begin{abstract}
ABSTRAK
Penelitian ini dilakukan untuk melihat seberapa besar pengaruh pemeriksaan pajak melalui kepatuhan wajib pajak dan dampaknya terhadap efektivitas penerimaan pajak penghasilan badan. Manfaat penelitian ini untuk menambah ilmu pengetahuan bagi penulis, memberi masukan kepada Kantor Pelayanan Pajak Pratama Bandung Tegallega, Kantor Pelayanan Pajak Pratama Majalaya, dan Kantor Pelayanan Pajak Pratama Cibeunying tentang pemeriksaan pajak, kepatuhan wajib pajak dan efektivitas penerimaan pajak penghasilan badan. Dan manfaat bagi akademisi menjadi referensi dalam melakukan penelitian-penelitian selanjutnya.

Metode yang digunakan adalah metode path analysis, dan teknik pengumpulan data dengan cara penyebaran kuesioner. Pengolahan data dilakukan dengan metode statistik nonparametrik dengan menggunakan analisis regresi berganda.

Hasil path analysis membuktikan bahwa (a) Pemeriksaan pajak berpengaruh signifikan sebesar 57,3\%. (b) Pemeriksaan pajak dan kepatuhan wajib pajak berpengaruh tidak signifikan sebesar $68,7 \%$ terhadap efektivitas penerimaan pajak penghasilan badan. (c) Pemeriksaan pajak berpengaruh sebesar 9,6\% terhadap efektivitas penerimaan pajak penghasilan badan melaui kepatuhanwajib pajak.
\end{abstract}

Kata Kunci : Pemeriksaan pajak, Kepatuhan Wajib Pajak, Efektivitas Penerimaan Pajak Penghasilan Badan. 


\section{ABSTRACT \\ INFLUENCE OF TAX EXAMINATIOSON COMPULSORY OF TAXPAYER AND INPACTON EFFECTIVENESS OF INCOME TAX INCOME}

This research is conducted to see how big the influence of tax audit through taxpayer compliance and its impact to effectiveness of income tax of body. The benefit of this research is to increase knowledge for writer, give input to Tax Office Pratama Bandung Tegallega, Primary Tax Service Office Majalaya, and Tax Office Pratama Cibeunying about tax examination, taxpayer compliance and effectiveness of corporate income tax. And the benefits for academics to be a reference in doing further research.

The method used is the method of path analysis, and data collection techniques by means of distributing questionnaires. Data processing was done by nonparametric statistic method by using multiple regression analysis.

Result of path analysis proves that (a) Tax examination have significant effect 57,3\%. (b) Tax audit and taxpayer compliance has an insignificant effect of $68.7 \%$ on the effectiveness of corporate income tax. (c) Tax audits have an effect of $9.6 \%$ on the effectiveness of corporate income tax returns through taxpayer compliance.

Keywords : Tax audit, Taxpayer Compliance, Effectiveness of Income Tax Income Agency.

\section{PENDAHULUAN}

Penerimaan pajak di Indonesia masih kecil sekali, masih banyak ruang yang bisa efisien untuk menambah APBN. Dibawah kepemimpinan Presiden Jokowi harus ada rekor penerimaan pajak tiap tahunnya. Presiden Jokowi yakin hal itu bisa tercapai, apalagi pembayaran pajak telah ditunjang dengan sistem online. Dengan rasio dan tax rasio di Indonesia masih $11 \%$, jadi masih ada ruang dinaikkan baik pribadi, PPn badan ruang itu yang ingin dikerjakan dan perlu diekstensifikasi. Untuk diketahui,
Direktorat Jenderal Pajak (DJP) Kementrian keuangan telah mengumpulkan penerimaan pajak lebih dari Rp. 1.000 triliun hingga 25 Desember 2015. Pencapaian tersebut merupakan prestasi bagi Ditjen Pajak karena berhasil mencetak rekor pertama kali dalam sejarah Indonesia. Pemerintah sendiri sebenarnya mematok target penerimaan pajak tahun 2016 Rp. 1.294,5 triliun. Penerimaan pajak yang tembus lebih dari Rp. 1.000 triliun berasal dari sumber pungutan baik Pajak Penghasilan (PPh), Pajak Penjualan (PPn), Pajak pertambahan 
Nilai (PPN), dan lainnya. (Jokowi, 2016).

Pemerintah menyadari kondisi ekonomi yang begitu baik akan berdampak pada penerimaan pajak. Oleh karena itu, perlu sejumlah strategi khusus untuk mengamankan penerimaan negara. Dalam mengamankan penerimaan rutin berarti seluruh kepala kantor harus melihat apa yang pernah dan sudah pernah diterima dari tahun sebelumnya, dari wajib pajak yang sudah dikenal itu harusnya kalaupun ada koreksi, dia koreksi yang dipertanggungjawabkan. Perlu usaha ekstra untuk mengamankan penerimaan pajak. Oleh karena itu, perlu adanya pemetaan terhadap penerimaan rutin pajak. (Sri Mulyani, 2016).

Dibawah ini adalah data tentang target dan realisasi penerimaan negara dari sektor Pajak Penghasilan Badan di KPP Pratama Bandung Tegallega dan KPP Pratama Majalaya.

\section{Grafik 1}

Target dan Realisasi Penerimaan Negara dari Sektor PPh Badan

KPP Pratama Bandung Tegallega

Tahun 2011 s/d 2015 (Milyar Rupiah)

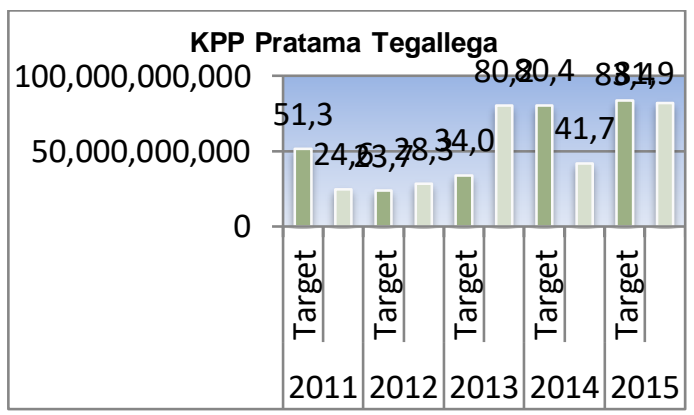

Sumber : KPP Pratama Bandung Tegallega, (data diolah), 2017

Berdasarkan data di atas penerimaan Pajak Penghasilan Badan setiap tahun fluktuatif. Tahun 2011 realisasi penerimaan $\mathrm{PPh}$ sebesar 48,0\%, tahun 2012 sebesar $119,6 \%$, tahun 2013 sebesar 235,5\%, tahun 2014 sebesar 51,9\% dan tahun 2015 sebesar 98,1\%. Jadi realisasi penerimaan $\mathrm{PPh}$ Badan di KPP Pratama Tegallega dalam 5 tahun terakhir hanya tercapai pada tahun 2012 dan tahun 2013, sedangkan tahun 2011, 2014, dan tahun 2015 realisasi penerimaan PPh Badan tidak tercapai sesuai dengan target yang telah ditetapkan.

Grafik 2

Target dan Realisasi Penerimaan Negara dari Sektor PPh Badan KPP Pratama Majalaya

Tahun 2011 s/d 2015 (Milyar Rupiah)

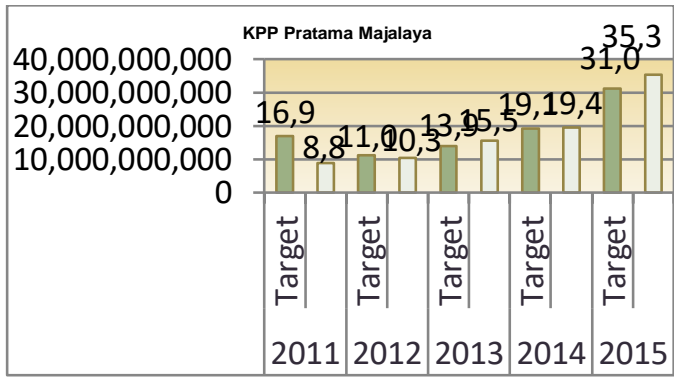

Sumber : KPP Pratama Majalaya, (data diolah), 2017

Berdasarkan data di atas penerimaan Pajak Penghasilan Badan setiap tahun fluktuatif. Tahun 2011 realisasi penerimaan PPh Badan sebesar 52,1\%, 
tahun 2012 sebesar 93,7\%, tahun 2013

sebesar 111,7\%, tahun 2014 sebesar 101,9\% dan tahun 2015 sebesar 113,6\%. Jadi realisasi penerimaan PPh Badan di KPP Pratama Majalaya dalam 5 tahun terakhir tercapai pada tahun 2013, 2014 dan tahun 2015, sedangkan tahun 2011 dan tahun 2012 realisasi penerimaan $\mathrm{PPh}$ Badan tidak tercapai sesuai dengan target yang telah ditetapkan.

Kepatuhan wajib pajak merupakan persoalan laten dan aktual yang sejak dulu ada di bidang perpajakan di Indonesia, wajib pajak yang tidak patuh maka akan menimbulkan keinginan untuk melakukan tindakan penghindaran, pengelakan, penyelundupan dan pelalaian pajak, yang pada akhirnya tindakan tersebut akan menyebabkan penerimaan pajak negara akan berkurang. Di bawah ini terdapat beberapa kasus mengenai kepatuhan wajib pajak badan diantaranya sebagai berikut :

Tabel 1

Rekapitulasi Kasus Kepatuhan Wajib Pajak yang Berkaitan dengan Penerimaan Pajak Penghasilan Badan tahun 2017

\begin{tabular}{ll}
\hline No & \multicolumn{1}{c}{ Kasus } \\
\hline 1 & Kanwil DJP Sumatera Utara, untuk \\
& mengamankan penerimaan pajak akan \\
& fokus kepada tindakan penegakan
\end{tabular}

\begin{tabular}{|c|c|}
\hline & $\begin{array}{l}\text { hukum yang meliputi pemeriksaan, } \\
\text { penyidikan, penagihan aktif, sampai } \\
\text { penyanderaan. }\end{array}$ \\
\hline 2 & $\begin{array}{l}\text { KPP Pratama Cibeunying, menyita } \\
\text { tanah milik PT. PDAP yang berlokasi di } \\
\text { Subang Jawa Barat akibat tunggakan } \\
\text { pajak yang tidak dilunasi sebesar } \\
\text { Rp.412 juta. }\end{array}$ \\
\hline 3 & $\begin{array}{l}\text { KPP Pratama Cibeuying, menyita } \\
\text { satu unit mobil milik PT. DMS di } \\
\text { Bandung yang tidak melunasi tung- } \\
\text { gakan pajak sebesar Rp.629 juta. }\end{array}$ \\
\hline 4 & $\begin{array}{l}\text { KPP Pratama Palembang Ilir Timur, } \\
\text { melakukan penyitaan aset berupa } 2 \\
\text { buah kendaraan bermotor milik WP } \\
\text { Badan Usaha dengan sisa tunggakan } \\
\text { pajak sebesar Rp.2,285 Milyar }\end{array}$ \\
\hline 5 & $\begin{array}{l}\text { KPP Pratama Gorontalo, melakukan } \\
\text { penyanderaan (gijzeling) terhadap dua } \\
\text { orang penanggung pajak dari PT. UA } \\
\text { dan CV U, Kedua perusahaan yang ber- } \\
\text { gerak di bidang konstruksi perkantoran } \\
\text { serta pengembangan perumahan ini } \\
\text { mempunyai utang pajak sebesar Rp. } \\
617.299 .370,- \text {. }\end{array}$ \\
\hline
\end{tabular}

Sumber : (Dokumentasi Penulis, 2017)

Dari tabel 1 di atas, menunjukan masih adanya kasus yang terkait dengan kepatuhan wajib pajak yang terjadi pada tahun 2017.

Kanwil DJP Jawa Barat I telah melakukan pendekatan kepada Wajib Pajak agar memenuhi Kewajiban Pajaknya, namun hingga batas waktu yang telah ditentukan wajib pajak belum juga melunasi tunggakan pajaknya, pihak Kanwil DJP Jawa Barat I akan bertindak tegas terhadap para penunggak pajak yang berada di wilayahnya. Tindakan ini merupakan komitmen DJP untuk membuat masyarakat patuh membayar pajak. 
Kepatuhan membayar pajak akan memberikan kontribusi yang sangat besar terhadap penerimaan negara. (Yoyok Satiotomo, 2017).

Kepatuhan perpajakan dapat didefinisikan sebagai suatu keadaan dimana wajib pajak memenuhi semua kewajiban perpajakannya dan melaksanakan hak perpajakannya (Safri Nurmantu, Siti Kurnia Rahayu, 2010:138).

Dibawah ini adalah data tentang refleksi tingkat kepatuhan wajib Pajak Badan di KPP Pratama Bandung Tegallega dan KPP Pratama Majalaya.

\section{Grafik 3}

Tingkat Refleksi Kepatuhan Wajib Pajak Badan

KPP Pratama Bandung Tegallega Tahun 2011 s/d 2015 (Dalam Ribuan)

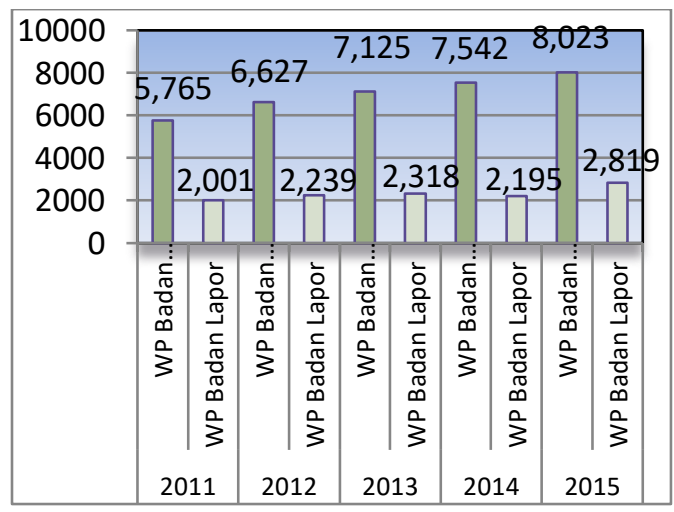

Sumber : KPP Pratama Bandung Tegallega, (data diolah), 2017

Berdasarkan data di atas tingkat refleksi tingkat kepatuhan wajib pajak badan setiap tahun fluktuatif. Tahun 2011 tingkat refleksi kepatuhan wajib pajak badan sebesar 34,7\%, tahun 2012 sebesar 33,7\%, tahun 2013 sebesar $32,5 \%$, tahun 2014 sebesar $29,1 \%$ dan tahun 2015 sebesar 35,1\%. Jadi tingkat refleksi kepatuhan wajib pajak badan di KPP Pratama Tegallega dengan presentasi tertinggi yaitu di tahun 2015 dan tahun 2011.

\section{Grafik 4}

Tingkat Refleksi Kepatuhan Wajib Pajak Badan

KPP Pratama Majalaya

Tahun 2011 s/d 2015 (Dalam Ribuan)

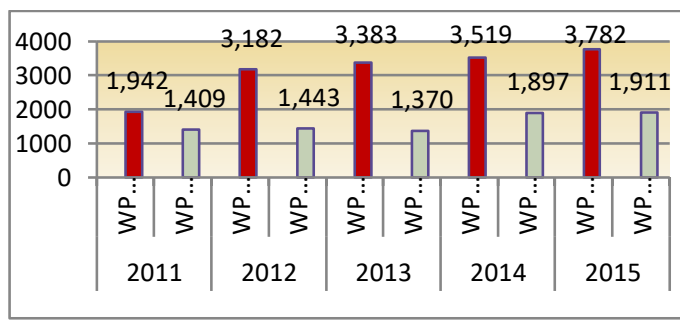

Sumber : KPP Pratama Bandung Majalaya,

(data diolah), 2017

Berdasarkan data di atas tingkat refleksi tingkat kepatuhan wajib pajak badan setiap tahun fluktuatif. Tahun 2011 tingkat refleksi kepatuhan wajib pajak badan sebesar 72,5\%, tahun 2012 sebesar 45,3\%, tahun 2013 sebesar 40,4\%, tahun 2014 sebesar 53,9\% dan tahun 2015 sebesar 50,5\%. Jadi tingkat refleksi kepatuhan wajib pajak badan di KPP Pratama Majalaya dengan presentasi tertinggi yaitu di tahun 2011 dan tahun 2014. 
Berdasarkan Undang-Undang No. 28 Tahun 2007 Pasal 1 angka 25 sebagaimana telah diubah terakhir dengan Undang-Undang No.16 Tahun 2009 bahwa pemeriksaan pajak adalah :

"Pemeriksaan pajak adalah serangkaian kegiatan menghimpun dana, mengolah data, keterangan, dan/atau bukti yang dilaksanakan secara objektif dan profesional berdasarkan suatu standar pemeriksaan untuk menguji kepatuhan pemenuhan kewajiban perpajakan dan/atau untuk tujuan lain dalam rangka melaksanakan ketentuan peraturan perundangundangan perpajakan".

Dari beberapa uraian di atas, dapat disimpulkan bahwa kegiatan pemeriksaan yang dilakukan bertujuan untuk menguji kepatuhan wajib pajak dalam memenuhi kewajiban perpajakannya, sehingga dari hasil pemeriksaan akan diketahui tingkat kepatuhan wajib pajak, bagi wajib pajak yang tingkat kepatuhannya rendah, diharapkan dengan dilakukannya pemeriksaan terhadapnya dapat memberikan motivasi positif agar untuk masa-masa selanjutnya menjadi lebih baik.

Dibawah ini adalah data wajib Pajak Badan yang diperiksa di KPP
Pratama Bandung Tegallega, KPP Pratama Majalaya dan KPP Pratama Bandung Cibeunying.

\section{Grafik 5}

Wajib Pajak Badan yang Diperiksa KPP Pratama Bandung Tegallega Tahun 2011 s/d 2015 (Dalam Ribuan)

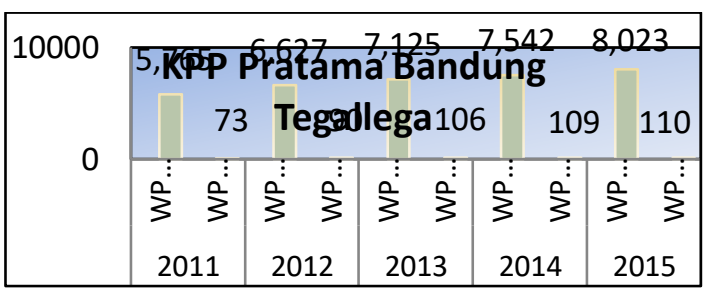

Sumber : KPP Pratama Tegallega (data diolah), 2017

Berdasarkan data di atas jumlah wajib pajak badan yang diperiksa setiap tahun fluktuatif. Tahun 2011 jumlah wajib pajak badan yang diperiksa sebesar $1,26 \%$, tahun 2012 sebesar 1,35\%, tahun 2013 sebesar 1,48\%, tahun 2014 sebesar 1,44\% dan tahun 2015 sebesar $1,37 \%$. Jadi jumlah wajib pajak badan yang diperiksa di KPP Pratama Bandung Tegallega dengan presentasi tertinggi yaitu di tahun 2013 dan tahun 2014.

\section{Gambar 6}

Wajib Pajak Badan yang Diperiksa

KPP Pratama Bandung Tegallega

Tahun 2011 s/d 2015 (Dalam Ribuan)

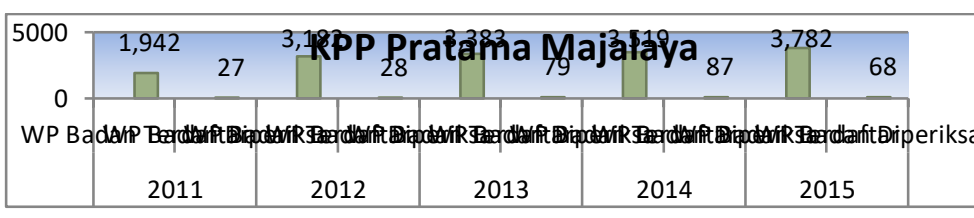

Sumber : KPP Pratama Majalaya (data diolah), 2017 
Berdasarkan data di atas jumlah wajib pajak badan yang diperiksa setiap tahun fluktuatif. Tahun 2011 jumlah wajib pajak badan yang diperiksa sebesar $1,39 \%$, tahun 2012 sebesar $0,87 \%$, tahun 2013 sebesar 2,33\%, tahun 2014 sebesar 2,47\% dan tahun 2015 sebesar $1,79 \%$. Jadi jumlah wajib pajak badan yang diperiksa di KPP Pratama Bandung Majalaya dengan presentasi tertinggi yaitu di tahun 2013 dan tahun 2014.

Penelitian sejenis telah dilakukan oleh Arya Erwin Safitri (2010), dengan judul Pengaruh Jumlah Pemeriksaan Pajak dan Sanksi Perpajakan terhadap Penerimaan Pajak Penghasilan dengan Kepatuhan Wajib Pajak sebagai Variabel Intervening dengan hasil bahwa jumlah pemeriksaan pajak, sanksi perpajakan dan kepatuhan wajib pajak berpengaruh signifikan terhadap penerimaan pajak penghasilan, Andy Wijiayanto (2012) dengan judul Pengaruh Pemeriksaan Pajak terhadap Penerimaan Pajak dengan hasil bahwa pemeriksaan pajak berpengaruh signifikan terhadap penerimaan pajak, Rahma Yeni (2013) dengan judul Pengaruh Tingkat Kepatuhan wajib Pajak Badan terhadap Peningkatan Penerimaan Pajak yang Dimoderasi oleh Pemeriksaan Pajak Pada KPP
Pratama Padang dengan hasil bahwa tingkat kepatuhan wajib pajak badan berpengaruh positif terhadap peningkatan penerimaan pajak, Neneng Aisyah (2013) dengan judul Pengaruh Pemeriksaan Pajak terhadap Kepatuhan Wajib Pajak dan Implikasinya terhadap Penerimaan Pajak dengan hasil bahwa pemeriksaan pajak berpengaruh positif terhadap kepatuhan wajib pajak, Rizki Yuslam Primerdo (2015) dengan judul Pengaruh Pemeriksaan Pajak dan Pengaruh Pajak Terhadap Efektivitas Penerimaan Pajak dengan hasil bahwa pemeriksaan pajak dan penagihan pajak berpengaruh terhadap efektivitas penerimaan pajak.

Berdasarkan uraian di atas maka penulis tertarik untuk melakukan penelitian dengan judul "Pengaruh Pemeriksaan Pajak terhadap Kepatuhan Wajib Pajak dan Dampaknya Terhadap Efektivitas Penerimaan Pajak Penghasilan Badan". (Survey di 3 KPP Pratama di Bandung).

\section{Identifikasi Masalah}

Identifikasi masalah dalam penelitian ini adalah :

1. Seberapa besar pengaruh pemeriksaan pajak terhadap kepatuhan wajib pajak. 
2. Seberapa besar pengaruh pemeriksaan pajak dan kepatuhan wajib pajak terhadap efektivitas penerimaan pajak penghasilan badan.

3. Seberapa besar pengaruh pemeriksaan pajak melalui kepatuhan wajib pajak terhadap efektivitas penerimaan pajak penghasilan badan.

\section{KAJIAN PUSTAKA DAN \\ KERANGKA PEMIKIRAN}

\section{Definisi Pemeriksaan Pajak}

Pengertian pemeriksaan pajak menurut Pasal 1 angka 25 Undang-undang momor 6 Tahun 1983 tantang Ketentuan Umum dan Tata Cara Perpajakan sebagaimana telah diubah terakhir dengan Undang-Undang Republik Indonesia Nomor 16 tahun 2009 adalah :

"Pemeriksaan pajak adalah serangkaiana kegiatan menghimpun dana, mengolah data, keterangan, dan/atau bukti yang dilaksanakan secara objektif dan profesional berdasarkan suatu standar pemeriksaan untuk menguji kepatuhanpemenuhan kewajiban perpajakan dan/atau untuk tujuan lain dalam rangka melaksanakan ketentuan peraturan perundangundangan perpajakan”.

Pengertian pemeriksaan pajak menurut Peraturan Menteri Keuangan Nomor 82/PMK.03/2011 tentang Tata
Cara Pemeriksaan Pajak Pasal 1 ayat (2) yang berbunyi :

"Pemeriksaan adalah serangkaian kegiatan menghimpun dan mengolah data, keterangan, dan / atau bukti yang dilaksanakan secara objektif dan profesional berdasarkan suatu standar pemeriksaan untuk menguji kepatuhan pemenuhan kewajiban perpajakan dan/ atau untuk tujuan lain dalam rangka melaksanakan ketentuan peraturan perundang - undangan perpajakan".

Pemeriksaan pajak adalah serangkaian kegiatan menghimpun dan mengolah data, keterangan, dan/atau bukti yang dilaksanakan secara objektif dan profesional berdasarkan suatu standar pemeriksaan untuk menguji kepatuhan pemenuhan kewajiban perpajakan dan/atau untuk tujuan lain dalamrangka melaksanakan ketentuan perundang-undangan perpajakan (Abdul Halim, dkk 2016 : 35).

Dari beberapa pengertian di atas, dapat disimpulkan bahwa pemeriksaan pajak adalah serangkaian kegiatan menghimpun dana, mengolah data atau keterangan lainnya yang digunakan untuk menguji kepatuhan pemenuhan kewajiban perpajakan dan untuk melaksanakan ketentuan perundang - 
undangan perpajakan (Abdul

Halim:2016).

\section{Dimensi dan Indikator Pemeriksaan}

\section{Pajak}

(Siti Kurnia Rahayu, 2010 :

286) indikator dari pemeriksaan pajak adalah :

1. Persiapan Pemeriksaan

Persiapan pemeriksaan adalah serangkaian kegiatan yang dilakukan oleh pememeriksa sebelum melaksanakan tindakan pemeriksaan dan meliputi kegiatan sebagai berikut :
a. Mempelajari berkas wajib pajak atau berkas data
b. Menganalisis SPT dan laporan keuangan wajib pa- jak
c. Mengidentifikas masalah
d. Melakukan pengenalan lo- kasi wajib pajak
e. Menentukan ruang lingkup pemeriksaan
f. Menyusun program pemeriksaan
g. Menentukan buku - buku dan dokumen yang akan dipinjam
h. Menyediakan sarana pemeriksaan

2. Pelaksanaan Pemeriksaan

Pelaksanaan pemeriksaan adalah serangkaian kegiatan yang dilakukan pemeriksa dan meliputi : a. Memeriksa di tempat Wajib Pajak

b. Melakukan Penilaian atas sistem pengendalian Internal

c. Memutahirkan ruang lingkup dan program pemeriksaan

d. Melakukan pemeriksaan atas buku - buku, catatan - catatan dan dokumen - dokumen

e. Melakukan konfirmasi kepada pihak ketiga

f. Memberitahukan hasil pemeriksaan kepada wajib pajak

g. Melakukan sidang penutup (closing conference)

3. Laporan Hasil Pemeriksaan

Laporan pemeriksaan pajak adalah laporan yang dibuat oleh pemeriksa pada akhir laporan pemeriksaan pelaksanaan yang merupakan ikhtisar dan penuangan semua hasil pelaksanaan tugas pemeriksaan sesuai dengan tujuan yang telah ditetapkan.

Adapun sistematika penyusunan laporan pemeriksaan pajak adalah sebagai berikut :
a. Umum
b. Pelaksanaan pemeriksaan
c. Hasil Pemeriksaan
d. Kesimpulan dan usul pemeriksaan

\section{Kepatuhan Wajib Pajak}

Menurut Safri nurmantu yang dikutip dari Siti kurnia Rahayu (2010:138) mengatakan bahwa kepatu- 
han perpajakan dapat didefinisikan sebagai suatu kedaan dimana wajib pajak memenuhi semua kewajiban perpajakan dan mekasanakan hak perpajakan.

Kepatuhan wajib pajak yang dikemukakan oleh Norman d. Nowark dalam Siti Kurnia Rahayu (2013 : 138) sebagai "Suatu iklim kepatuhan dan kesadaran pemenuhan kewajiban perpajakan, tercermin dalam situasi dimana :

1. Wajib pajak paham atau berusaha untuk memahami semua ketentuan peraturan perundang - undangan perpajakan.

2. Mengisi formulir pajak dengan lengkap dan jelas

3. Menghitung jumlah pajak yang terutang dengan benar

4. Membayar pajak yang terutang tepat pada waktunya.

Kepatuhan wajib pajak merupakan pemenuhan kewajiban perpajakan yang dilakukan oleh pembayar pajak dalam rangka memberikan kontribusi bagi pembangunan, dewasa ini yang diharapkan di dalam pemenuhannya diberikan sukarela. Kepatuhan wajib Pajak menjadi aspek penting mengingat sistem perpajakan Indonesia menganut sistem Self Asessment dimana dalam prosesnya secara mutlak memberikan kepercayaan kepada wajib pajak untuk menghitung, membayar dan melaporkan kewajibannya, dengan tujuan pada penerimaan pajak yang optimal. (Widi Widodo: 2010)

\section{Dimensi Kepatuhan Wajib Pajak Kepatuhan Formal}

Widi Widodo (2010 : 138)

bahwa yang dapat diidentifikasi sebagai kewajiban wajib pajak dalam perpajakan adalah hal-hal berikut dimana dapat diteliti sebagai dimensi kepatuhan formal Dalam Undang-Undang No.28 Tahun 2007 sebagaimana telah diubah dengan Undang-Undang Nomor 16 tahun 2009, bahwa dimensi kepatuhan wajib pajak adalah sebagai berikut :

1. Pasal 2 ayat (1) perihal pendaftaran dan pengukuhan

"Setiap wajib pajak yang telah memenuhi persyaratan subjektif dan objektif sesuai dengan ketentuan peraturan perundang undangan perpajakan wajib mendaftarkan diri kepada Direktorat Jenderal Pajak yang wilayah kerjanya meliputi tempat tinggal atau tempat kedudukan wajib pajak dan kepadanya diberikan Nomor Pokok Wajib Pajak".

2. Pasal 2 ayat (2) perihal pendaftaran dan pengukuhan

"Setiap Wajib Pajak sebagai pengusaha yang dikenai pajak berdasarkan Undang - Undang Pajak Pertambahan Nilai 1984 dan perubahannya, wajib pajak melaporkaPn usahanya pada 
Kantor Direktorat Denderal Pajak yang wilayah kerjanya meliputi tempat tinggal atau tempat kedudukan pengusaha, dan tempat kegiatan uasaha dalakukan untuk dikukuhkan menjadi Pengusaha Kena Pajak".

3. Pasal 3 ayat (1) perihal Kewajiban menyampaikan SPT

"Setiap wajib pajak wajib nengisi Surat Pemberitahuan dengan benar, lengkap, dan jelas, dalam bahasa Indonesia menggunakan huruf latin, angka Arab, satuan mata uang rupiah, dan menandatanagi serta menyampaikannya ke Kantor Direktorat Jenderal Pajak tempat Wajib Pajak terdaftar atau dikukuhkan atau tempat lain yang ditetapkan oleh Direktorat Jenderal Pajak".

4. Pasal 3 ayat (3) perihal Batas Waktu Penyampaian SPT

Batas waktu penyampaian Surat Pemberitahuan Pajak adalah :

a. Untuk Surat Pemberitahuan Masa, paling lama 20 (dua puluh) hari setelah akhir masa pajak

b. Untuk Surat Pemberitahuan Tahunan Pajak Penghasilan Wajib Pajak Orang pribadi,paling lama 3 (tiga) bulan setelah akhir tahun pajak; atau

c. Untuk Surat Pemberitahuan Tahunan Pajak Penghasilan Wajib Pajak Badan, paling lama 4 (empat) bulan setelah akhir tahun pajak.

5. Pasal 9 ayat (1) perihal pembayaran dan penyetoran pajak "Menteri Keuangan menentukan tanggal jatuh tempo pembayaran dan penyetoran pajak yang terutang untuk suatu saat atau Masa pajak bagi masing - masing jenis pajak, paling lama 15 (lima belas) hari setelah saat terutangnya pajak atau berakhirnya Masa Pajak “.

\section{Kepatuhan Material}

Kepatuhan material adalah suatu keadaan dimana wajib pajak secara substantive atau hakekatnya memenuhi semua ketentuan material perpajakan, yakni sesuai isi dan dan jiwa Undang- Undang perpajakan. (Siti Kurnia Rahayu, 2013:138)

Menurut Widi Widodo (2010 : 70) yang dapat diidentifikasi dari kepatuhan material antara lain :

1) Kesesuaian jumlah kewajiban pajak yang harus dibayar dengan perhitungan sebenarnya

Berdasarkan Undang - Undang No.16 Tahun 2009 tentang KUP pada pasal 12 ayat (1) meyebutkan bahwa setiap wajib pajak membayar pajak yang terutang sesuai dengan ketentuan perundang - undangan perpajakan, dengan tidak menggantungkan pada adanya surat ketetapan pajak.

2) Penghargaan terhadap independensi akuntan publik / konsultan pajak Wajib Pajak berhak menggunakan jasa akuntan publik atau konsultan pajak untuk membantu melakukan kewajiban pajaknya. Dalam kaitan jasa yang diberikan akuntan publik / konsultan pajak tersebut, wajib pajak yang memenuhi ketentuan kapatuhan material, harus menghargai prinsip independensi sebagai dasar 
pemberian jasa mereka. Dalam konteks ini, Wajib Pajak tidak berusaha untuk mempengaruhi akuntan publik / konsultan pajak agar bertindak sesuai dengan keinginan mereka.

3) Besar / Kecilnya jumlah tunggakan pajak

Undang-Undang No.28 Tahun 2009 tentang KUP pada pasal 20 ayat (1) menyebutkan bahwa atas jumlah pajak yang masih harus dibayar yang berdasarkan Surat Tagihan Pajak, Surat Ketetapan Pajak Kurang Bayar,Serta Surat ketetapan Pajak Kurang Bayar Tambahan, dan Surat Keputusan Pembetulan, Surat Keputusan Keberatan, Putusan Banding, serta Putusan Peninjauan Kembali yang menyebabkan jumlah pajak yang masih harus dibayar bertambah, yang tidak dibayar oleh penanggung pajak sesuai dengan jangka waktu sebagaimana dimaksud dalam pasal 9 ayat (3) atau ayat 3 (a) dilaksanakan penagihan dengan Surat Paksa sesuai dengan peraturan perundang-undangan perpajakan.

\section{Penerimaan Pajak}

Menurut Dearmando (2012) yang dikutip dalam penelitian Yuniati (2015), bahwa penerimaan Pajak adalah semua penerimaan yang terdiri dari $\mathrm{Pa}-$ jak Dalam Negeri dan Pajak Perdagangan Internasional. Pajak Dalam Negeri adalah semua penerimaan Negara yang berasal dari Pajak Penghasilan. Menurut Tw Silalahi (2014), penerimaan Pajak merupakan slah satu sumber utama penerimaan negara disamping penerimaan bukan Pajak seperti migas dan non migas. Menurut Siimettablebh (2010), penerimaan Pajak dapat diartikan sebagai penerimaan pemerintah yang dalam arti seluas-luasnya adalah mulai dari penerimaan dalam dan luar negeri, penerimaan Pajak dianggap sebagai bagian yang sangat penting dalam penerimaan Negara, karena Pajak merupakan sumber penerimaan yang sangat penting potensinya.

Menurut Ardiyansarutobi (2010) yang dikutip dalam penelitian Yuniati (2015), penerimaan Pajak adalah semua penerimaan yang terdiri dari Pajak dalam Negeri dan Pajak Perdagangan Internasional. Pajak dalam negeri terdiri atas Pajak Penghasilan (PPh), Pajak Pertambahan Nilai Barang dan Jasa (PPn) dan Pajak Penjualan atas Barang Mewah (PPnBM), Pajak Bumi Dan Bangunan (PBB), bea perolehan hak atas tanah dan bangunan (BPHTB), dan pajak lainnya. Untuk Pajak perdagangan Internasional terdiri atas bea masuk dan pajak / pungutan ekspor.

Dari uraian di atas dapat disimpulkan penerimaan Pajak adalah semua penerimaan Negara yang terdiri dari Pajak dalam Negeri yang berasal dari Pajak Penghasilan, dan Pajak Perdagangan Internasional, (Dearmando : 2012, Tw Silalahi : 2014, Siimettableh : 2010).

\section{Efekivitas Penerimaan Pajak Pengha- silan}

Adapun cara menilai efektivitas terhadap penerimaan Pajak Penghasilan mengacu pada pasal 7 Undang-Undang No.16 Tahun 2009 tentang perubahan keempat atas Undang-Undang No.28 Tahun 2007 tentang PPh yaitu cara melihat

1) Kepatuhan wajib pajak dalam melaksanakan pembayaran dan pelaporan pajak penghasilan 
2) Penerapan sanksi pajak penghasilan

3) Target penerimaan Pajak Penghasilan

Menurut pasal 29 (1) UndangUndang No.16 Tahun 2009 tentang perubahan keempat atas Undang-Undang No. 28 tahun 2007 tentang ketentuan umum dan tata cara perpajakan adalah sebagai berikut :

"Direktorat Jenderal Pajak berwenang melakukan peeriksaan untuk menguji kepatuhan kewajiban perpajakan Wajib Pajak dan untuk tujuan lain dalam rangka melaksanakan ketentuan peraturan perundangundangan perpajakan".

Menurut Sasmita (2013) yang dikutip dalam penelitian Yuniati (2015), strategi pengamanan penerimaan pajak dibagi dalam tiga bidang, yaitu bidang kebijakan, kepatuhan, dan kegiatan pendukung. Dalam kebijakan Ditjen Pajak menetapkan langkah seperti rancangan Peraturan Menteri Keuangan tentang Peraturan Pajak Penghasilan Final. Dalam bidang kegiatan pendukung ditetapkan empat strategi, yaitu pengembangan kapasitas SDM terutama pada account representayive dan pemeriksa pajak, penambahan sumber daya manusia (SDM) secara bertahap, pengalokasian SDM yang lebih tepat sesuai dengan potensi dan kopetensi, menyiapkan kelengkapan operasional dan logistik untuk mendukung kebijakan di bidang perpajakan, serta pengembangan kapasitas SDM terutama pada account representative dan pemeriksa pajak.

Menurut Surat Edaran Direktur Jenderal Pajak Nomor SE-15/PJ/2014, terdapat rencana strategis Direktorat Jenderal Pajak Tahun 2012-2014, salah satu penjabaran misi yang dilaksanakan Direktorat Jenderal Pajak dalam mencapai visi untuk menghimpun penerimaan Negara secara optimal adalah peningkatan efektivitas pengawasan. Oleh karena itu efektivitas pemeriksaan menjadi sasaran strategis yang harus dicapaioleh Direktorat Jenderal Pajak.

Dari uraian di atas, dapat diambil kesimpulan bahwa efektivitas penerimaan pajak tidak dapat diukur melalui angka-angka terinci, tetapi efektivitas penerimaan pajak dapat diukur melalui besaran yang sifatnya kualitatif yaitu pencapaian tujuan dan sasaran yang telah ditetapkan, yang bisa dinilai dengan cara melihat kepatuhan wajib pajak dalam melaksanakan pembayaran dan pelaporan pajak penghasilan, penerapan sanksi Pajak Penghasilan, target penerimaan Pajak Penghasilan, ( UU No.16 Tahun 2009, Sasmita :2013, Surat Edaran Direktur Jendera

1 Pajak SE-15/PJ/2014). 


\section{Definisi Pajak Penghasilan Badan}

Pada pasal 1 UU Pajak Penghasi-

lan Nomor 36 tahun 2008, Pajak Pengha-

silan adalah Pajak terhadap subjek pajak

atas penghasilan yang diterima atau diperolehnya dalam tahun pajak. Pajak Penghasilan Badan (PPh Badan) adalah pajak yang dikenakan atas penghasilan yang diterima atau diperoleh oleh Badan seperti yang dimaksud dalam UU KUP No. 16 Tahun 2009
1. Wajib Pajak Badan Dalam Negeri, yaitu badan yang didirikan atau bertempat kedudukan di Indonesia.

2. Wajib Pajak Badan Luar Negeri, yaitu badan yang tidak didirikan atau tidak bertempat kedudukan di Indonesia yang menjalankan usaha atau melakukan kegiatan melalui BUT di Indonesia, dan atau badan yang tidak didirikan dan tidak bertempat kedudukan di Indonesia yang menerima penghasilan dari Indonesia tidak dari menjalankan usaha melalui BUT di Indonesia

Gambar 1

Bagan Kerangka Pemikiran

Pengaruh Pemeriksaan Pajak terhadap Kepatuhan Wajib Pajak dan Dampaknya terhadap Efektivitas Penerimaan Pajak Penghasilan Badan

\begin{tabular}{|c|c|c|}
\hline $\begin{array}{l}\text { Rekapitulasi Kasus Kepatuahan Wajib Pajak di } \\
\text { Indonesia tahun } 2017 \\
\text { - Tindakan penegakan hukum untuk nengamankan } \\
\text { penerimaan pajak oleh Kanwil DJP Sumatera Urata. } \\
\text { - Penyitaan aset PT. PDAP dan PT. DMS oleh KPP } \\
\text { Pratama Cibeunying karena tidak melunasi tung- } \\
\text { gakan pajak } \\
\text { - Penyitaan aset milik WP badan usaha oleh KPP } \\
\text { Pratama Palembang Ilir Timur } \\
\text { - Penyanderaan oleh KPP Pratama Gorontalo ter- } \\
\text { hadap menanggung pajak PT. UA dan CV. U, ka- } \\
\text { rena utang pajak }\end{array}$ & $\begin{array}{l}\text { KPP Pratama Bandung Tegallega } \\
\text { - Realisasi penerimaan PPh Badan } \\
\text { tidak tercapai pada tahun 2011, } \\
2014 \text { dan tahun } 2015 \\
\text { - Tingkat kepatuhan Wajib Pajak pal- } \\
\text { ing rendah tahun } 2014 \\
\text { - WP Badan yang paling banyak di- } \\
\text { periksa tahun } 2013\end{array}$ & $\begin{array}{l}\text { KPP Pratama Majalaya } \\
\text { - Realisasi penerimaan PPh Badan } \\
\text { tidak tercapai pada tahun 2011, } \\
\text { dan tahun } 2012 \\
\text { - Tingkat kepatuhan Wajib Pajak } \\
\text { paling rendah tahun } 2013 \\
\text { - WP Badan yang paling banyak } \\
\text { diperiksa tahun } 2013\end{array}$ \\
\hline
\end{tabular}

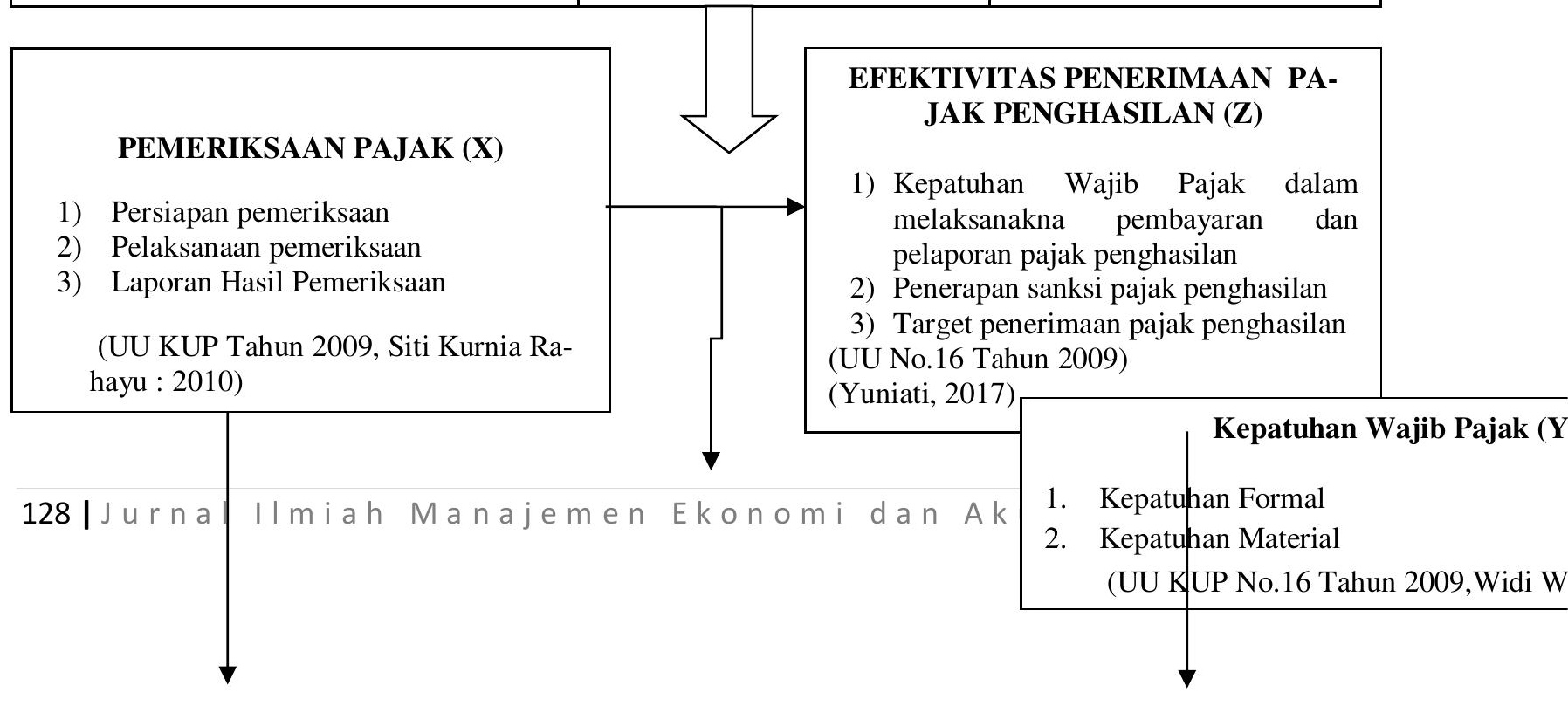




\section{PENELITIAN SEBELUMYA}

Arya Erwin Safitri (2010), Andy Wijiayanto (2012), Rahma Yeni (2013), Neneng Aisyah (2013), Rizki Yuslam Primerdo (2015) .

Gambar 2

Gambar 2
Pemeriksaan Pajak

(X)
Efektivitas Penerimaan Pajak Penghasilan Badan

(Z)

\section{Paradigma Penelitian}

Hipotesis Penelitian

Pengaruh Pemeriksaaan pajak terhadap kepatuhan wajib pajak

Pemeriksaan pajak adalah serangkaian kegiatan meghimpun dana, mengolah data atau keterangan lainnya yang digunakan untuk menguji kepatuhan pemenuhan kewajiban perpajakan dan untuk melaksanakan ketentuan Perundang-Undangan. Variabel pemeriksaan pajak disini memiliki pengaruh terhadap kepatuhan wajib pajak. Hal ini didukung oleh penelitian yang dilakukan oleh Arya Erwin Safitri (2010)

$\mathrm{H}_{1}$ : Pemeriksaan Pajak berpengaruh terhadap Kepatuhan Wajib Pajak. Semakin baik pemeriksaan pajak maka akan meningkatkan kepatuhan wajib pajak

Pengaruh Pemeriksaan Pajak dan Kepatuhan Wajib Pajak terhadap Efektivitas Penerimaan Pajak Penghasilan Badan

Kepatuhan perpajakan adalah suatu keadaan dimana wajib pajak memenuhi semua kewajiban perpajakannya dan 
melaksanakan hak perpajakanya. Variabel Pemeriksaan Pajak dan Kepatuhan Wajib Pajak disini memiliki pengaruh positif terhadap Penerimaan Pajak. Hal ini didukung oleh penelitian yang dilakukan oleh Neneng Aisyah (2013).

$\mathrm{H}_{2}$ : Pemeriksaan Pajak dan Kepatuhan Wajib Pajak berpengaruh terhadap Efektivitas Penerimaan Pajak Penghasilan Badan. Semakin baik pemeriksaan pajak dan kepatuhan wajib pajak akan meningkatkan penerimaan pajak penghasilan badan.

\section{Pengaruh Pemeriksaan Pajak melalui Kepatuhan Wajib Pajak terhadap Efektivitas Penerimaan Pajak Penghasilan Badan}

Pajak Penghasilan (PPh) adalah yang dikenakan terhadap Subjek Pajak atas Penghasilan yang diterima atau diperolehnya dalam satu tahun pajak. Variabel pemeriksaan Pajak melalui Kepatuhan Wajib Pajak disini memiliki pengaruh positif terhadap Efektivitas Penerimaan Pajak Penghasilan Badan. Hal ini didukung oleh penelitian yang dilakukan oleh Rizki Yuslam (2015).

$\mathrm{H}_{3}$ : Pemeriksaan Pajak melalui Kepatuhan Wajib Pajak berpengaruh secara langsung dan tidak langsung terhadap Efektivitas Penerimaan Pajak Penghasilan Badan. Semakin baik pemeriksaan pajak dengan didukung kepatuhan dari wajib pajak akan meningkatkan penerimaan pajak penghasilan badan.

\section{Metodologi Penelitian}

Dalam penelitian ini jenis penelitiannya adalah penelitian deskriptif kuntitatif untuk mengetahui seberapa besar pengaruh Pemeriksaan Pajak terhadap Kepatuhan Wajib Pajak dan dampaknya terhadap Efektivitas Penerimaan Pajak Penghasilan Badan di KPP Pratama Bandung Tegallega, KPP Pratama Majalaya dan KPP Pratama Cibeunying.

Menurut Sugiyono (2014:61), pengertian populasi adalah wilayah generalisasi yang terdiri atas objek / subjek yang mempunyai kualitas dan mempunyai karakteristik tertentu yang ditetapkan oleh peneliti untuk dipelajari dan kemudian ditarik kesimpulannya.

Populasi dalam penelitian ini adalah seluruh bagian pemeriksaan yang ada di KPP Pratama Bandung Tegallega, KPP Pratama Majalaya, dan KPP Pratama Cibeunying

Menurut Sugiyono (2014:81), pengertian sampel adalah bagian dari jumlah dan karakteristik yang dimiliki oleh populasi tersebut. Dalam penelitian ini, teknik pengambilan sampel menggunakan purposive sampling yaitu teknik pengambilan sampel sumber data dengan pertimbangan tertentu. 
Dari uraian di atas, sampel yang digunakan adalah seluruh bagian pemeriksaan pajak yang ada di KPP Pratama Bandung Terallega, KPP Pratama Majalaya dan KPP Pratama Cibeunying dengan jumlah bagian pemeriksaan berjumlah 30 orang.

\section{Uji Analisis Jalur (Path Analysis)}

Menurut Menurut Riduwan (2013:1), pengertian path analysis yang diartikan oleh Bohrnstedt (1974 dalamKusnaedi, 2005:1) bahwa "a technique for estimating the effect's a set of independent variables has on dependent variable froma set of observed correlations, given a set of hypothesized causal asymertic relation among the variables". Sedangkan tujuan utama path analysis adalah " $a$ method of measuring the direct influence along each separate path in such a system and thus of finding the degree to which variation of a given effect is determined by each particular cause. The method depend on the combination of the knowledge of the degree of correlation among the variable in a system with such knowledge as may possessed of the causal relations (Maruyama,1998:16).

Jadi, path analysis dapat digunakan untuk menganalisis pola hubungan antar variabel dengan tujuan untuk mengetahui pengaruh langsung maupun tidak langsung seperangkat variabel bebas (eksogen) terhadap variabel terikan (endogen).

Kerangka Hubungan Kausal Empiris Model Path Analysis Uji Path Analysis model 1
Pengujian secara Individual Pemeriksaan Pajak (X) terhadap Kepatuhan Wajib Pajak (Y)

Hipotesis penelitian yang diuji dirumuskan dalam bentuk hipotesis statistik sebagai berikut :

$$
\begin{aligned}
& \mathrm{H}_{\mathrm{a}}: \mathrm{p}_{\mathrm{yx}}>0 \\
& \mathrm{H}_{\mathrm{o}}: \mathrm{p}_{\mathrm{yx}}=0
\end{aligned}
$$

Dimana :

$\mathrm{H}_{\mathrm{a}}$ : Pemeriksaan Pajak berkontribusi terhadap Kepatuhan Wajib Pajak

$\mathrm{H}_{\mathrm{o}}$ : Pemeriksaan Pajak tidak berkontribusi terhadap Kepatuhan Wajib Pajak.

Kerangka hubungan kausal empiris X terhadap Y dapat dibuat melalui persamaa struktural Model 1 sebagai berikut :

\begin{tabular}{|l|}
\hline $\mathrm{Y}=\mathrm{p}_{\mathrm{yx}} \mathrm{X}+\mathrm{p}_{\mathrm{y}} \mathrm{e} 1$ \\
Dengan, \\
$\mathrm{e} 1=\sqrt{1-\text { Ryx }}$ \\
\hline
\end{tabular}

Keterangan :

$\mathrm{Y}=$ Kepatuhan Wajib Pajak

$\mathrm{X}=$ Pemeriksaan Pajak

$\mathrm{P}_{\mathrm{yx}} \quad=$ Standardized Coefficients Beta Variabel X model 1

$\mathrm{P}_{\mathrm{y}} \quad=$ Variabel sisa

e $1=$ Penyimpangan model 2

Ryx $=R$ square model 1

Dari persamaan di atas diperoleh

diagram model 1 sebagai berikut :

Gambar 3

Bentuk Diagram Model 1

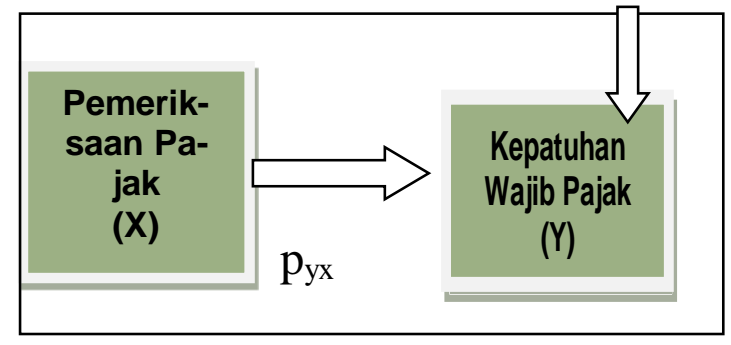


Uji Path Analysis model 2

Pengujian secara Individual Kepatuhan Wajib Pajak (Y) terhadap Efektivitas Penerimaan PPh Badan (Y)

Hipotesis penelitian yang diuji dirumuskan dalam bentuk hipotesis statistik sebagai berikut :

\begin{tabular}{|l|}
$\mathrm{H}_{\mathrm{a}}: \mathrm{p}_{\mathrm{zy}}>0$ \\
$\mathrm{H}_{\mathrm{o}}: \mathrm{p}_{\mathrm{zy}}=0$ \\
\hline
\end{tabular}

Dimana :

$\mathrm{H}_{\mathrm{a}}$ : Kepatuhan Wajib Pajak berkontribusi terhadap Efektivitas Penerimaan PPh Badan

$\mathrm{H}_{\mathrm{o}}$ : Kepatuhan Wajib Pajak tidak berkontribusi terhadap Efektivitas Penerimaan PPh Badan

Kerangka hubungan kausal empiris $\mathrm{X}$, dan $\mathrm{Y}$ terhadap $\mathrm{Z}$ dapat dibuat melalui persamaa struktural Model 1 sebagai berikut :

$$
\mathrm{Z}=\mathrm{p}_{\mathrm{zX}} \mathrm{X}+\mathrm{p}_{\mathrm{zy}} \mathrm{Y}+\mathrm{p}_{\mathrm{z}} \mathrm{e} 2
$$

Dengan,

e $2=\sqrt{1-R z y}$

Keterangan :

$\mathrm{Z}=$ Efektivitas Penerimaan Pajak Penghasilan

$\mathrm{X}=$ Pemeriksaan Pajak

$\mathrm{P}_{\mathrm{zx}} \quad=$ Standardized Coefficients Beta variabel X model 2

$\mathrm{P}_{\mathrm{zy}} \quad=$ Standardized Coefficients Beta variabel Y model 2

$\mathrm{P}_{\mathrm{z}} \quad=$ Variabel sisa

e 2 = Penyimpangan model 2

Ryx $=R$ square model 2

Dari persamaan di atas diperoleh

diagram model 1 sebagai berikut :

Gambar 4

Model Jalur 2

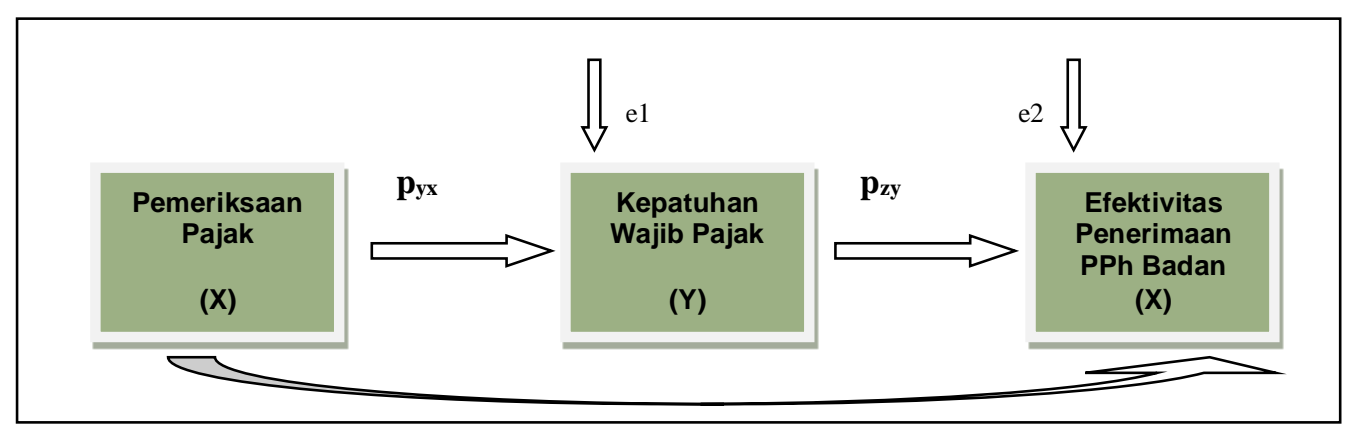

HASIL PENELITIAN DAN PEMBAHASAN

\section{Uji Analisis Jalur (Path Analysis)}

Uji analisis jalur dalam

penelitian ini megnggunakan alat bantu

SPSS 23, yang dapat dilihat pada tabel di bawah ini.

\section{Uji Path Analysis model I}

Berikut ini adalah tabel yang menunjukan hasil dari pengujian variabel Pemeriksaan Pajak (X) terhadap Kepatuhan Wajib Pajak (Y)

Tabel 2

Coefficient Model 1 Sub-Struktur 1 
VOL. 2 NO. 2 JANUARI - JUNI 2018 e-ISSN: 2621-5306

VOL. III NO. 1 JANUARI - JUNI 2018 p-ISSN: 2541-5255

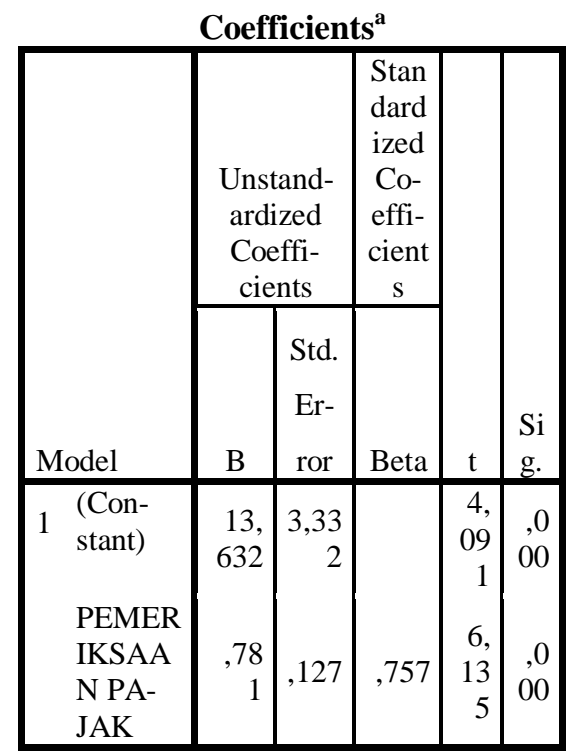

a. Dependent Variable: KEPATU-

HAN WAJIB PAJAK

Sumber : Hasil SPSS 23 yang sudah diolah 
Berdasarkan tabel 2 di atas, diketahui bahwa nilai signifikansi dari variabel Pemeriksaan Pajak $(X)=0,000$ lebih kecil dari 0,05. Sehingga dapat disimpulkan bahwa Regresi Model I, yaitu Variabel Pemeriksaan Pajak (X) berpengaruh signifikan terhadap Kepatuhan Wajib Pajak. Kerangka kausal hubungan empiris X terhadap Y melalui persamaan sebagai berikut :

$$
\mathrm{Y}=\mathrm{p}_{\mathrm{yx}} \mathrm{X}+\mathrm{p}_{\mathrm{y} \text { e } 1}
$$$$
Y=0,757+0,6534
$$

\section{Dengan}

e $1=\sqrt{1-0,573}$

e $1=0,6534$
Model Summary Model 1 Sub-Struktur 1

\begin{tabular}{|l|r|r|r|r|}
\hline $\begin{array}{l}\text { Mode } \\
1\end{array}$ & $\mathrm{R}$ & \multicolumn{1}{|c|}{ Model Summary } \\
Square & $\begin{array}{c}\text { Adjusted R } \\
\text { Square }\end{array}$ & $\begin{array}{l}\text { Std. Error of } \\
\text { the Estimate }\end{array}$ \\
\hline 1 &, $757^{\mathrm{a}}$ &, 573 &, 558 & 1,884 \\
\hline
\end{tabular}

Predictors: (Constant), PEMERIKSAAN PAJAK Sumber : Hasil SPSS 23 yang sudah diolah

Berdasarakan tabel 3 di atas, diketahui bahwa nilai $R$ Square adalah sebesar 0,573. Hal ini menunjukan bahwa pengaruh Pemeriksaan Pajak (X) terhadap Kepatuhan Wajib Pajak (Y) adalah sebesar 57,3\%, sementara sisanya $(1-57,3)$ yaitu $42,7 \%$ merupakan kontribusi dari variabel-variabel lain yang didak diteliti dalam penelitian ini. Sementara itu untuk nilai e1 dapat diketahui yaitu $\mathrm{e} 1=\sqrt{(1-0,573)}=0,6534$. Dengan demikian maka diperoleh diagram jalur model 1 struktur 1 yang disajikan dalam gambar 4.7 sebagai berikut:

Tabel 3 
Gambar 5

Diagram Jalur Model I

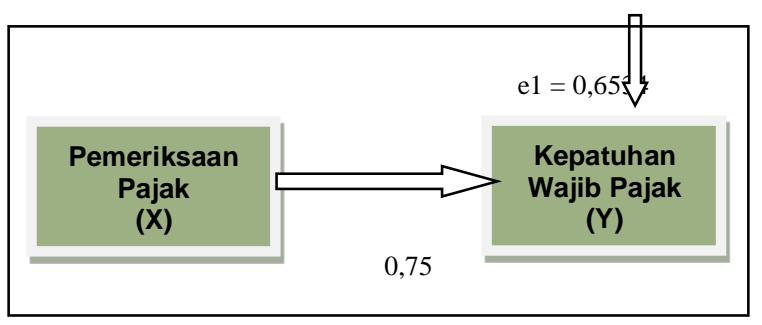

\section{Uji Path Analysis model II}

Berikut ini adalah tabel yang menunjukan hasil dari pengujian variabel Pemeriksaan Pajak (X) dan Kepatuhan Wajib Pajak (Y) terhadap Efektivitas Penerimaan Pajak Penghasilan Badan (Z).

Tabel 4

Model Coefiicients Model II Sub-Struktur 2

Coefficients $^{\mathrm{a}}$

\begin{tabular}{|c|c|c|c|c|c|c|}
\hline \multirow{2}{*}{\multicolumn{2}{|c|}{ Model }} & \multicolumn{2}{|c|}{ Unstandardized Coefficients } & \multirow{2}{*}{$\begin{array}{c}\text { Standardized } \\
\text { Coefficients } \\
\text { Beta }\end{array}$} & \multirow[b]{2}{*}{$\mathrm{t}$} & \multirow[b]{2}{*}{ Sig. } \\
\hline & & $\mathrm{B}$ & Std. Error & & & \\
\hline \multirow[t]{4}{*}{1} & (Constant) & 1,105 & 3,038 & & ,364 & ,719 \\
\hline & PEMERIKSAAN PAJAK & ,622 &, 141 & ,728 & 4,420 &, 000 \\
\hline & KEPATUHAN WAJIB & 105 & 126 & 127 & 777 & 146 \\
\hline & PAJAK & , & 150 & (12) & 2, & , 440 \\
\hline
\end{tabular}

a. Dependent Variable: EFEKTIVITAS PENERIMAAN PAJAK PENGHASILAN BADAN Sumber : Hasil SPSS 23 yang sudah diolah

Berdasarkan tabel 4 di atas, diketahui bahwa nilai signifikansi dari variabel Pemeriksaan Pajak (X) yaitu $\mathrm{X}=$ 0,000 lebih kecil dari 0,05 dan Kepatuhan Wajib Pajak (Y) yaitu $\mathrm{Y}=$ 0,446 lebih besar dari 0,05. Dengan demikian dapat disimpulkan bahwa Regresi Model II yaitu Pemeriksaan Pajak (X) dan Kepatuhan Wajib Pajak (Y) berpengaruh tidak signifikan terhadap Efektivitas Penerimaan Pajak Penghasilan Badan (Z). Kerangka kausal hubungan empiris $\mathrm{X}$ dan $\mathrm{Y}$ terhadap $\mathrm{Z}$ melalui persamaan sebagai berikut :

$Z=p_{z x} X+p_{y z} Y+p_{z} e 2$

$Z=0,728+0,127+0,5674$

Dengan

$\mathrm{p}_{\mathrm{Z}} \mathrm{e} 2=\sqrt{1-0,687}$

pze2 $=0,5674$

Dibawah ini terdapat model summary model II sruktur 2 yang 
disajikan dalam tabel 4.24 sebagai

berikut :

Tabel 5

Model Summary Model II Sub-Struktur 2

Model Summary

\begin{tabular}{|l|r|r|r|r|}
\hline Model & \multicolumn{1}{|c|}{ R } & \multicolumn{1}{c|}{ R Square } & \multicolumn{1}{c|}{ Adjusted R Square } & \multicolumn{1}{c|}{$\begin{array}{c}\text { Std. Error of the Esti- } \\
\text { mate }\end{array}$} \\
\hline 1 &, $829^{\mathrm{a}}$ &, 687 &, 664 & 1,359 \\
\hline
\end{tabular}

a. Predictors: (Constant), KEPATUHAN WAJIB PAJAK, PEMERIKSAAN PAJAK

Sumber : Hasil SPSS 23 yang sudah diolah

Berdasarkan tabel 5 di atas besarnya nilai $R$ Square adalah sebesar 0,678 hal ini menunjukan bahwa Pemeriksaan Pajak (X) dan Kepatuhan Wajib Pajak (Y) Terhadap Efektivitas Pemerimaan Pajak Penghasilan Badan sebesar $68,7 \%$ sementara sisanya (1-68,7) yaitu 31,3 \% merupakan kontribusi dari variabel variabel yang tidak diteliti dalam penelitian ini. Sementara untuk nilai e2 = $\sqrt{(1-0,678)}=0,5674$. Dengan demikian maka diperoleh diagram jalur model II struktur 2 yang disajikan dalam gambar 4.7 sebagai berikut:

Gambar 6

Model Jalur 2

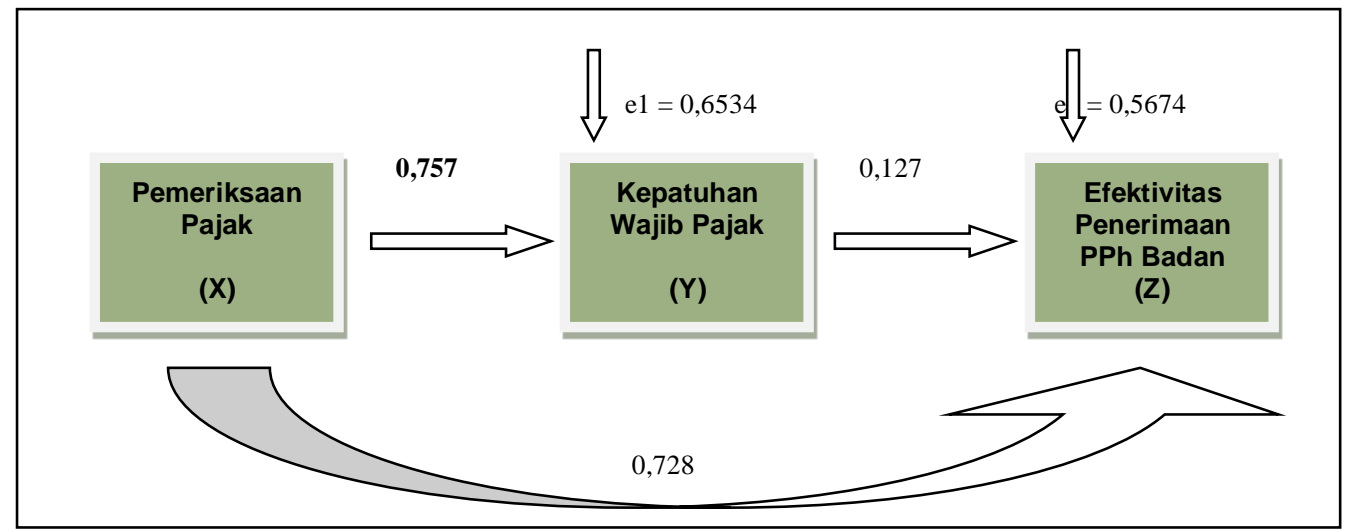




\section{Hasil Uji Hipotesis}

Hasil Uji Hipotesis menggunakan analisis dibantu SPSS 23 sebagai berikut

\section{Analisis Pengaruh Pemerik-} saan Pajak (X) terhadap Kepatuhan Wajib Pajak (Y)

Dari analisis di atas diperoleh nilai signifikansi Pemeriksaan Pajak (X) sebesar 0,000 < 0,005 sehingga dapat disimpulkan bahwa secara langsung terdapat pengaruh signifikan Pemeriksaan Pajak (X) terhadap Kepatuhan Wajib Pajak (Y).

Sesuai dengan tujuannya berdasarkan sebagaimana dimaksudkan dalam Keputusan Menteri Keuangan No.545/KMK 04/2000 tanggal 22 Desember 2000 bahwa tujuan pemeriksaan adalah untuk menguji kepatuhan pemenuhan kewajiban perpajakan dalam rangka memberikan kepastian hukum, keadilan dan pembinaan kepda wajib pajak dan tujuan lain dalam rangka melaksanakan ketentuan pe- rundang-undangan perpajakan. Oleh karenaitu dari hasil pemeriksaan akan diketahui tingkat kepatuhan wajib pajak, bagi wajib pajak yang tingkat kepatuhannya yang tergolong rendah,diharapkan dengan dilakukannya pemeriksaan terhadapnya dapat memberikan motivasi positif agar untuk masa-masa selanjutnya mejadi lebih baik.

\section{Analisis Pengaruh Pemerik-} saan Pajak (X) terhadap Efektivitas Penerimaan PPh

\section{$\operatorname{Badan}(\mathbf{Z})$}

Dari analisis diperoleh nilai signifikansi Pemeriksaan Pajak $(\mathrm{X})$ sebesar 0,000 0,05. Sehingga dapat disimpulkan bahwa secara langsung terdapat pengaruh signifikan Pemeriksaan Pajak (X) terhadap Efektivitas Penerimaan PPh Badan (Z).

Menurut Erly Suandy (2008:93) yang dikutip dari Karlina Oktaviani (2017) menjelaskan bahwa tujuan dari pemeriksaan pajak adalah 
untuk meningkatkan penerimaan pajak dan pemeriksaan pajak dapat meningkatkan kepatuhan (tax complete), melalui upaya-upaya penegakan hukum (law inforcement) sehingga dapat meningkatkan penerimaan pajak.

3. Analisis Pengaruh Kepatuhan Wajib Pajak (Y) terhadap Efektivitas Penerimaan PPh Badan (Z)

Dari analisis diperoleh nilai signifikansi Kepatuhan Wajib Pajak (Y) sebesar 0,446 > 0,05 . Sehingga dapat disimpulkan bahwa secara langsung terdapat pengaruh tidak signifikan Kepatuhan Wajib Pajak (Y) terhadap Efektivitas Penerimaan PPh Badan (Z).

Sebagaimana yang dikemukakan oleh Siti Resmi (2013:140) yang menyatakan bahwa masalah Kepatuhan Wajib Pajak adalah masalah penting di seluruh dunia, baik di negara maju maupun di negara berkembang. Karena wajib pajak yang tidak patuh maka akan menimbulkan keinginan untuk melakukan tindakan penghindaran, pengelakan, penyeludupan dan pelalaian pajak. Yang pada akhirnya tindakan tersebut akan meyebabkan penerimaan pajak negara akan berkurang.

4. Analisis Pengaruh Pemeriksaan Pajak (X) melalui Kepatuhan Wajib Pajak (Y) terhadap Efektivitas Penerimaan PPh Badan (Z)

Berdasarkan hasil uji analisis di atas, diketahui pengaruh langsung yang diberikan Pemeriksaan Pajak (X) terhadap Efektivitas Penerimaan PPh Badan (Z) 0,728. Sedangkan pengaruh tidak langsung Pemeriksaan Pajak (X) melalui Kepatuhan Wajib Pajak (Y) terhadap Efektivitas Penerimaan PPh Badan (Z) adalah perkalian antara nilai beta $\mathrm{X}$ terhadap $\mathrm{Y}$ dengan nilai beta $\mathrm{Y}$ terhadap $\mathrm{Z}$ yaitu $0,757 \times 0,127=0,096$. Maka pengaruh total yang diberikan Pemeriksaan Pajak (X) terhadap Efektivitas Penerimaan 
PPh Badan (Z) adalah pengaruh langsung ditambah dengan pengaruh tidak langsung yaitu $=0,728+0,096=$ 0,824. Berdasarkan hasil perhitungan di atas diketahui bahwa nilai pengaruh langsung sebesar 0,728 dan pengaruh tidak langsung 0,096 yang berarti bahwa nilai pengaruh langsung lebih besar dibandingkan pengaruh tidak langsung. Hasil ini menunjukan secara langsung Pemeriksaan Pajak (X) mempunyai pengaruh signifikan terhadap Efektivitas penerimaan Pajak Penghasilan Badan (Z) tanpa melaui Kepatuhan Wajib Pajak (Y).

Menurut Erly Suandy (2008:93) yang dikutip dari Karlina Oktaviani (2017) menjelaskan bahwa tujuan dari pemeriksaan pajak adalah untuk meningkatkan penerimaan pajak dan pemeriksaan pajak dapat meningkatkan kepatuhan (tax complete), melalui upaya-upaya pene- gakan hukum (law inforcement) sehingga dapat meningkatkan penerimaan pajak. Oleh karena itu pemeriksaan pajak melalui kepatuhan wajib pajak berdampak pada efektivitas penerimaan pajak penghasilan. Jika pemeriksaan pajak ditingkatkan maka tingkat kepatuhan wajib pajak dan dapat meningkatkan efektivitas penerimaan pajak penghasilan badan.

\section{KESIMPULAN}

Berdasarkan pada data yang dikumpulkan dan pengujian yang dilakukan, maka dapat diambil kesimpulan sebagai berikut :

1. Pemeriksaan Pajak (X) berpengaruh sebesar $57,3 \%$ terhadap Kepatuhan Wajib Pajak (Y). Jadi semakin baik pemeriksaan maka akan meningkatkan kepatuhan Wajib Pajak.

2. Pemeriksaan Pajak (X) dan Kepatuhan Wajib Pajak (Y) berpengaruh sebesar $68,7 \%$ terhadap Efektivitas Penerimaan Pajak Penghasilan Badan (Z). Jadi semakin baik pemeriksaan pajak 
dan kepatuhan pajak akan meningkatkan penerimaan Pajak Penghasilan Badan.

3. Pemeriksaan Pajak (X) berpengaruh secara tidak langsung sebesar 9,6\% terhadap Efektivitas Penerimaan Pajak Penghasilan Badan (Z) melalui Kepatuhan Wajib Pajak (Y). Dan Pemeriksaan Pajak berpengaruh secara langsung terhadap Efektivitas Penerimaan PPh Badan sebesar $72,8 \%$. Jadi semakin baik pemeriksaan dengan didukung kepatuhan dari wajib pajak maka penerimaan Pajak Penghasilan semakin meningkat.

\section{SARAN}

1. Dari hasil penelitian pengaruh pemeriksaan pajak terhadap kepatuhan di Kantor Pelayanan Pajak Pratama Bandung Tegallega, Kantor Pelayanan Pajak Pratama Majalaya, dan Kantor Pelayanan Pajak Pratama Cibeunying, maka peneliti memberikan saran perlu ditingkatkan lagi untuk pemeriksaan pajak oleh bagian SDM dengan dilakukan pemeriksaan pajak secara periodik.

2. Dari hasil penelitian pengaruh pemeriksaan pajak dan Kepatuhan Wajib Pajak terhadap Efektivitas Penerimaan PPh Badan Kantor Pelayanan Pajak Pratama Bandung Tegallega, Kantor Pelayanan Pajak Pratama Majalaya, dan Kantor Pelayanan Pajak Pratama Cibeunying maka peneliti memberikan saran perlu adanya SDM yang berkualitas dan berdedikasi tinggi dan perlu dihindari mengenai kedekakan Wajib Pajak dengan Pegawai Pajak sehingga tidak terjadi kongkalingkong atau negosiasi dalam pemeriksaan pajak. Dan saran untuk Pemerintah dalam hal ini melalui Kementrian dan Dirjen Pajak agar membuat peraturan peraturan terhadap pemeriksaan secara periodik.

3. Dari hasil penelitian pengaruh pemeriksaan terhadap Kepatuhan Wajib Pajak dan dampaknya terhadap Efektivitas Penerimaan PPh Badan Kantor Pelayanan Pajak Pratama Bandung Tegallega, Kantor Pelayanan Pajak Pratama 
Majalaya, dan Kantor Pelayanan

Pajak Pratama Cibeunying maka peneliti memberikan saran dalam kategori kepatuhan material dan untuk efektivitas penerimaan pajak penghasilan badan perlu ditingkatkan dengan memberikan sosialisasi kepada wajib pajak .

\section{DAFTAR PUSTAKA}

Abdul Halim dkk. 2014. Perpajakan Konsep, Aplikasi, Contoh, Dan Studi Kasus. Salemba Empat : Jakarta

Yuniati. 2016. Perpajakan Teori, Konsep \& Praktik. Pena Sakti Ilmu : Bandung

Yuniati. 2017. Pemotongan/Pemungutan $\mathrm{PPH}$. Konsep, Contoh, dan Studi Kasus. Pena Sakti Ilmu : Bandung

Siti Resmi. 2014. Perpajakan. Teori dan Kasus. Salemba Empat : Jakarta

Siti Kurnia Rahayu. 2013. Perpajakan Indonesia, Konsep \& Aspek Formal. Graha Ilmu : Yogyakarta

Widi Widodo dkk. 2010. Moralitas, Budaya dan Kepatuhan Pajak. Alfabeta : Bandung
Ghozali, Imam. 2013. Aplikasi Analisis Multivariate dengan Program IBM SPSS Update PLS Regresi. Badan Penerbit Universitas Diponegoro : Semarang

Sugiyono. 2015. Statistik Untuk Penelitian. Alfabeta : Bandung

Husein Umar. 2013. Metode Penelitian Untuk Skripsi dan Tesis Bisnis. Rajawali Pers : Jakarta

Riduwan dkk. 2013. Cara Menggunakan dan Memaknai Path Analysis (Analisis Jalur). Alfabeta : Bandung

Yuniati. 2015. Pengaruh Pengendalian Intern Terhadap Efektivitas Penerimaan Pajak Penghasilan Pada Kantor Pelayanan Pajak Pratama Bandung Tegallega. Skripsi

Yuniati. 2017. The Influence Of Internal Control On The Effectiveness Of Income Tax Revenue. Vol. V, Issue 11, November 2017. ISSN 23480386

Arya Erwin Safitri. 2010. Pengaruh Jumlah Pemeriksaan Pajak dan Sanksi Perpajakan terhadap Penerimaan Pajak Penghasilan dengan Kepatuhan Wajib Pajak sebagai Variabel Intervening. Skripsi 
Andy Wijayanto. 2012. Pengaruh Pemeriksaan Pajak terhadap Penerimaan Pajak. Skripsi

Rahmayeni. 2013. Pengaruh Tingkat Kepatuhan Wajib Pajak Badan terhadap Peningkatan Penerimaan Pajak yang Dimoderasi oleh Pemeriksaan Pajak pada KPP PratamaPadang. Skripsi

Neneng Asyiah. 2013. Pengaruh Pemeriksaan Pajak terhadap Kepatuhan Wajib Pajak dan Implikasinya terhadap Penerimaan Pajak. Skripsi

Rizki Yuslam Primerdo. 2015. Pengaruh Pemeriksaan Pajak terhadap Efektivitas Penerimaan Pajak. Skripsi

Kartika Pratiwi Putri. 2015. Pengaruh Tingkat Pengetahuan Perpajakan Wajib Pajak dan Pelayana Fiskus (Aparat Pajak) terhadap Kepatuhan Pajak (Wajib Pajak Badan dan Orang Pribadi di Kota Bandung). Tesis

Surat Edaran SE-15/PJ/2014. Tentang Rencana Dan Strategi Pemeriksaan

Undang-Undang No.36 Tahun 2008. Pajak Penghasilan

Undang-Undang No.16 Tahun 2009. Ketentuan Umum dan Tata Cara Perpajakan
Sri Mulyani. 2017. Pengejaran Target Penerimaan Pajak, Melalui http://bisnis.liputan6.com/read/2645845/carasri-mulyani-kejar-penerimaan-pajak, diakses tanggal 6 April 2017 - 16.02

Jokowi. 2017. Rekor Penerimaan Pajak, Melalui http://bisnis.liputan6.com/read/2450573/joko wi-ingin-tiap-tahun-adarekor-penerimaan-pajak, diakses tanggal 6 April 2017 16.12

Sri Mulyani, 2017. Kepatuhan Wajib Pajak Memprihatinkan, Melalui

http://prokal.co/read/news/12 17-sri-mulyani-kepatuhanwajib-pajak-memprihatinkan.html, diakses tanggal 6 April 2017 - 16.40

Yoyok Sutiatomo. 2017. Ketentuan Pajak, Melaui http://ketentuan.pajak.go.id/index.php?r=aturan/rinci\&idcrypt $=$ oJefpJ $8 \% 3 \mathrm{D}, \quad$ diakses tanggal 6 April 2017 - 20.09

Kanwil DJP Sumatera Utara, Pengamanan Penerimaan Pajak, Melaui http://www.pajak.go.id/content/kanwil-djpsumut-i-apresiasi-seluruhpihak-dalam-pengamananpenerimaan-pajak, diakses tanggal 25 Juli $2017-16.51$ 
KPP Pratama Cibeunying, Penyitaan Aset PT. PDAP yang berlokasi di Subang Jawa Barat, Melaui http://www.pajak.go.id/content/tunggak-rp412-juta-kpp-cibeunying-sitaaset-penunggak-pajak, diakses tanggal 25 Juli 2017 17.22

KPP Pratama Cibeunying, Penyitaan Aset PT. DMS di Kota Bandung, Melalui, http://www.pajak.go.id/content/kantor-pajak-cibeunying-sita-hartapenunggak-pajak, diakses tanggal 25 Juli 2017 - 18.43 .

KPP Pratama Palembang Ilir Timur, Penyitaan Aset milik WP Badan Usaha,Melalui,http://www.pa- jak.go.id/sites/default/files/Sita\%20301\%2030 $\% 20$ Nov\%2016\%20release\%20p2humas.pdf, diakses tanggal 25 Juli 2017 19.17

KPP Pratama Gorontalo, Penyanderaan terhadap dua orang penanggung pajak, Melalui, http://www.pajak.go.id/content/tingkat-kepatuhan-wajibpajak-di-kanwil-sumatera-selatan-dan-kep-bangka-belitung, diakses tanggal 25 Juli $2017-20.05$ 